\section{In a global pandemic, sport and exercise medicine can mean so much more}

\author{
Jane S Thornton $\odot,{ }^{1}$ Karim M Khan $\oplus^{2}$
}

The COVID-19 pandemic has been challenging, if not overwhelming, for many patients and healthcare providers in our field. Consultants-turned-frontline healthcare workers, athletes losing access to their raison-d'être and even livelihood, researchers losing access to their labs. Competitive sport was hit hard, while physical activity levels soared for some as it provided escape from the land of lockdown. For people facing pre-existing socioeconomic and health inequities like women, Indigenous People, marginalised and racialised groups, patients in longterm care facilities and those with disabilities, the pandemic revealed the true magnitude of the physical inactivity crisis.

As sport and exercise clinicians and researchers, our advocacy on public health issues and unequal access to physical activity highlighted by the pandemic is critical. We have new opportunities to speak out and act on important policy issues as they arise. For example, we can champion for more walkable cities, broadcast the value of time being active outdoors, and remind the world of the positive effects of exercise on the immune system. We must also ensure proper screening and rehabilitation for our SARS-CoV-2 positive patients.

What have we learnt this year? This CASEM issue (see cover image) highlights three major topics:

1. Absence makes the heart grow fonder: now more than ever, we need sportas an important health-enhancing physical activity and a powerful unifying force. Steffan Griffin and team expand on these principles in the study of Rugby Union and health (see page 319), showing that all forms of the sport are health-enhancing and that 'non-contact' and wheelchair rugby

${ }^{1}$ Public Health and Family Medicine, University of Western Ontario Schulich School of Medicine and Dentistry, London, Ontario, Canada

${ }^{2}$ Family Practice \& Kinesiology, The University of British Columbia, Vancouver, British Columbia, Canada

Correspondence to Dr Jane S Thornton, Public Health and Family Medicine, University of Western Ontario Schulich School of Medicine and Dentistry, London, Canada; jane.s.thornton@gmail.com

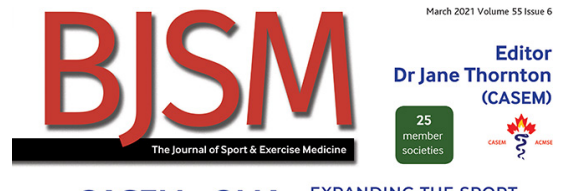

CASEM - OMA EXPANDING THE SPORT

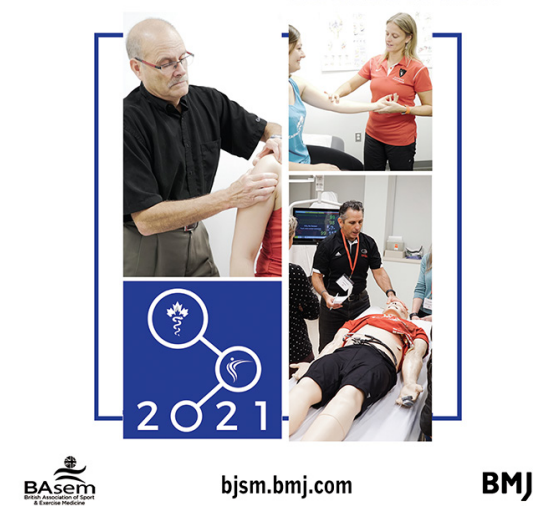

Figure 1

in particular 'provide a wide range of physical, and mental health and wellbeing benefits'. And this does not just apply to rugby. See this link for a review of golf. ${ }^{1}$

2. Even during a pandemic-do not lose sight of the climate crisis: last December, United Nations secretarygeneral, António Guterres, framed the climate crisis as a war on our planet. 'The way we are moving is a suicide', he said before stating that humanity's survival will be 'impossible' without action. ${ }^{2}$ Copenhagen's Lars Nybo and team stress that escalating temperatures are 'expected to influence performance and planning of several future football events'; the authors outline eight strategies to protect athletes' health (see page 297). Canadian authors Sean Notley and Glen Kenny, along with Aspetar's Sebastien Racinais, hypothesise that in hot-humid conditions such as those anticipated in Tokyo, female athletes in particular may benefit from longer-term heat acclimation and re-acclimation to maximise performance (see page 298).

3. COVID-19 is changing the way we do sports medicine: international collaboration by Herbert Lollgren and team resulted in a practical infographic to guide Return-to-Play decisions during the pandemic (see page 344) as sport and exercise medicine (SEM) clinicians proceed through uncharted territory. ${ }^{3-6}$ As the world goes virtual, that also means virtual SEM consultations and conferences, and a need for effective web-based patient resources. Corneel Vandelanotte and colleagues found that web-based personally tailored physical activity videos were no more effective in promoting physical activity than personally tailored text and generic information (see page 336), emphasising the need for further work in this space to rethink optimal design for patient engagement.

\section{CASEM, VIRTUALLY}

Canadian researchers and clinicians continue to make meaningful advances in our field and are well-represented in this issue (see pages 298, 300, 303 and 327). In May 2021, CASEM will once again enter the world of virtual learning, teaming up with the Ontario Medical Association Sport \& Exercise Medicine section to deliver a state-of-the-art annual scientific programme (figure 1). During the 2020-2021 year, CASEM president Dr Margaret Burghardt and her staff have delivered over 25 webinars by 35 different Canadian and international speakers. Attendances have passed 2000 - a definite benefit of the improved video platform.

\section{REACH OUT AND CHECK IN}

Today, perhaps more than ever before, the link between physical and mental health is undisputed. In BJSM's Patient Voices section, Canadian national basketball team player Emily Potter shares her story about ACL injury and its profound effect on her mental health (see page 349). 'I think a lot of physical things can be made worse if your mental health is suffering. You may try to treat the physical, but the easiest way to a solution might be the mental aspect of things ... Athletes need to be able to communicate what they're feeling, but sports and exercise medicine professionals need to know how to get feelings out of them'.

For clinicians, this is a good reminder that our athletes may be struggling with more than the injury or illness they came to see us about (see page 327) — especially during times of uncertainty; we have an opportunity and responsibility to ask if this is the case. Let us address our athletes' 
presenting issues and do as Ms Potter recommends-get feelings out of them. Once our own workday is done, we clinicians and researchers struggling through a global pandemic superimposed on the climate crisis-probably need to get our feelings out too. Liberate yourself to do this and ask for help if you need it.

Stay safe. Stay well. Stay active!

Correction notice This article has been corrected since it first published. The provenance and peer review statement has been included.

Twitter Jane S Thornton @janesthornton

Contributors Article concept and management: JST. Manuscript writing and editing: JST, KMK.

Funding The authors have not declared a specific grant for this research from any funding agency in the public, commercial or not-for-profit sectors.

Competing interests None declared.

Patient consent for publication Not required.
Provenance and peer review Commissioned internally peer reviewed.

This article is made freely available for use in accordance with BMJ's website terms and conditions for the duration of the covid-19 pandemic or until otherwise determined by BMJ. You may use, download and print the article for any lawful, non-commercial purpose (including text and data mining) provided that all copyright notices and trade marks are retained.

(c) Author(s) (or their employer(s)) 2021. No commercial re-use. See rights and permissions. Published by BMJ.

\section{Check for updates}

To cite Thornton JS, Khan KM. Br I Sports Med 2021:55:295-296

Accepted 10 December 2020

Br J Sports Med 2021:55:295-296.

doi:10.1136/bjsports-2020-103821

ORCID iDs

Jane S Thornton http://orcid.org/0000-0002-3519-7101 Karim M Khan http://orcid.org/0000-0002-9976-0258

\section{REFERENCES}

1 Murray AD, Daines L, Archibald D, et al. The relationships between golf and health: a scoping review. Br I Sports Med 2017;51:12-19.

2 . Available: https://www.theguardian.com/environment/ 2020/dec/02/us-biden-rejoining-paris-agreementun-secretary-general-climate-emissions [Accessed December 4, 2020].

3 Gervasi SF, Pengue L, Damato L, et al. Is extensive cardiopulmonary screening useful in athletes with previous asymptomatic or mild SARS-CoV-2 infection? Br J Sports Med 2021;55:54-61.

4 DiFiori JP, Green G, Meeuwisse W, et al. Return to sport for North American professional sport leagues in the context of COVID-19. Br J Sports Med 2020:doi: 10.1136/bjsports-2020-103227. [Epub ahead of print: 23 Sept 2020].

5 Jorstad HT, van den Aardweg JG. Balancing act: when is an elite athlete who has had COVID-19 safe to return to play? when does prudent investigation go offside into overmedicalising? Br J Sports Med 2020;54:1134-5.

6 Carmody S, Murray A, Borodina M, et al. When can professional sport recommence safely during the COVID-19 pandemic? risk assessment and factors to consider. Br J Sports Med 2020:54:946-8. 